\title{
Effects of acidifier added to diets containing graded levels of crystalline tryptophan on growth performance, protein digestibility, and on brain serotonin level in broiler chickens*
}

\author{
S. Smulikowska ${ }^{1}$ B. Pastuszewska, D. Tomaszewska-Zaremba, \\ L. Buraczewska, C.V. Nguyen and A. Mieczkowska
}

\author{
The Kielanowski Institute of Animal Physiology and Nutrition, \\ Polish Academy of Sciences \\ 05-110 Jabłonna, Poland
}

(Received 4 December 2003; accepted 9 April 2004)

\begin{abstract}
The objective of the study was to investigate whether addition of acidifier (A) to a diet containing crystalline tryptophan (TRP) does not impair utilization of the amino acid both for growth and serotonin synthesis in broiler chicken. Eight groups, each of 12 eight-day-old, individually housed, female broilers, were fed on diet containing $1.57 \mathrm{~g}$ TRP $/ \mathrm{kg}$, or diets supplemented with $0.21,0.42$ and $0.63 \mathrm{~g}$ TRP, without or with $3 \mathrm{~g}$ acidifier (A - mixture of phosphoric, citric and fumaric acids) per $\mathrm{kg}$. Feed intake and body weight (BW) was registered for 3 weeks, followed by balance experiment, at the end the birds were killed and digesta and brain tissue were sampled.

TRP supplementation increased BW gain and improved feed utilization $(\mathrm{P}<0.05)$, and did not affect ileal, while slightly decreased faecal protein digestibility. The concentration of serotonin (5-HT) and the ratio of 5-hydroxy-indole-3-acetic acid (5-HIAA) to 5-HT in brain tissue increased $(\mathrm{P}<0.01)$ with the increase of TRP level in diet. Supplementation with A had no significant effect on performance, $\mathrm{pH}$ of digesta, ileal and faecal protein digestibility in comparison with unsupplemented diets. However, it lowered the concentration of 5-HT (2.75 vs $2.98 \mu \mathrm{g} / \mathrm{g} ; \mathrm{P}<0.05)$ and increased the ratio of 5-HIAA/5-HT (0.30 vs $0.25 ; \mathrm{P}<0.01)$ in brain tissue, the negative effect was greatest in TRP deficient $\operatorname{diet}(\mathrm{TRP} \times \mathrm{A} ; \mathrm{P}<0.001)$. It indicate for a need of careful adjusting TRP level in broiler diets supplemented with acidifiers.
\end{abstract}

KEY WORDS: acidifiers, tryptophan, protein digestibility, serotonin, brain tissue, broiler chickens

\footnotetext{
* Supported by the State Committee for Scientific Research, Grant No. 3 P06 Z 02222. Part of the paper was presented on 14th European Symposium on Poultry Nutrition, 10-14 August, 2003, Lillehammer (Norway)

${ }^{1}$ Corresponding author: e-mail: s.smulikowska@ifzz.pan.pl
} 


\section{INTRODUCTION}

In broiler diets composed of common ingredients, as cereals and soyabean meal and of high protein content, the first-limiting amino acid is usually methionine followed by lysine. However, constraints on nitrogen pollution oblige producers to lower protein content and often soyabean meal is substituted by locally produced high-protein feedstuffs. In such situations it may be necessary to enrich diets with threonine and tryptophan to prevent deficiency of these amino acids. Crystalline forms of amino acids are supposed to be completely absorbed in the gut and fully available for anabolic purposes. Tryptophan (TRP) is utilized for body protein synthesis, but it is also a precursor of important non-protein substances, among others the neurotransmitter serotonin, which is involved in regulation of feed intake, resistance for stress and animal behaviour (Laycock and Ball, 1990; Rosebrough, 1996; Sève, 1999), and niacin, if diet is deficient in this vitamin (Baker et al., 1973).

Serotonin (5-HT) is synthetized from TRP through hydroxylase pathway with 5-hydroxytryptophan as an intermediate product. 5-HT if further oxidized to 5-hydroxy-indole-3-acetic acid (5-HIAA). The increase of brain 5-HT concentration in response to the increase of dietary and plasma levels of TRP was found in several studies in pigs (Sève, 1999) and in chicken (Rosebrough, 1996).

Various organic acids are presently added to chicken and pig diets, in the aim to improve the growth rate and/or feed utilization, the reduction of the intestinal microflora is indicated as one of possible modes of action of the acids (Vogt et al., 1982; Falkowski and Aherne, 1984; Patten and Waldroup, 1988; Izat et al., 1990; Roth and Kirchgessner, 1998). Acidification of poultry feed is also practiced in the aim to control contamination of poultry products with Salmonella sp. (Thompson and Hinton, 1997). Tryptophan is particularly sensitive to low $\mathrm{pH}$ and in acidified digesta it may be partly destroyed prior to absorption.

The objective of the study was to verify the hypothesis on the possible negative effect of acidification on utilization of crystalline tryptophan for growth, protein digestibility and deposition and serotonin synthesis in growing chickens.

\section{MATERIAL AND METHODS}

\section{Experimental design and diets}

Two experiments were performed. Experiment 1 was designed to check the effects of different acidifiers (A) on $\mathrm{pH}$ of digesta and to choose the most efficient preparation for use in main study. In Experiment 2 the effects of acidifier added to diets containing graded levels of TRP on nutritional parameters and on brain serotonin concentration were measured. A diet deficient in tryptophan was prepared from maize, wheat, yellow lupin and maize gluten (diet D; Table 1). 
TABLE 1

Composition of diets, $\mathrm{g} / \mathrm{kg}$

\begin{tabular}{|c|c|c|c|c|c|c|c|c|}
\hline \multirow{2}{*}{ Component } & \multicolumn{8}{|c|}{ Diets $^{1,2}$} \\
\hline & $\mathrm{D}^{2}$ & $\mathrm{~T} 1^{2}$ & $\mathrm{~T} 2^{2}$ & $\mathrm{~T} 3^{1,2}$ & $\mathrm{DA}^{2}$ & $\mathrm{TA} 1^{2}$ & $\mathrm{TA} 2^{2}$ & TA $3^{1,2}$ \\
\hline L-tryptophan (99\%) & - & 0.21 & 0.42 & 0.63 & - & 0.21 & 0.42 & 0.63 \\
\hline Acidifier $^{3}$ & - & - & - & - & 3.00 & 3.00 & 3.00 & 3.00 \\
\hline Maize starch & 3.63 & 3.42 & 3.21 & 3.00 & 0.63 & 0.42 & 0.21 & - \\
\hline Constant components ${ }^{4,5}$ & 996.37 & 996.37 & 996.37 & 996.37 & 996.37 & 996.37 & 996.37 & 996.37 \\
\hline Tryptophan $_{\text {total }}$ & 1.57 & 1.78 & 1.99 & 2.20 & 1.57 & 1.78 & 1.99 & 2.20 \\
\hline $\begin{array}{l}{ }^{1} \text { diets used in Experime } \\
{ }^{3} \text { in Experiment } 1 \text { : Acid L } \\
\text { Plus; in Experiment } 2 \text { : } \\
{ }^{4} \text { constant components pr } \\
\text { maize gluten } 118 \text {; soya } \\
\text { (99\%) } 0.6 \text {; L-threonine } \\
11 \text {; dicalcium phosphat } \\
3500 \text { IU; Ca } 1.075 \mathrm{~g} ; \mathrm{m} \\
\text { niacin } 60 \text {; folic acid } 1.7 \\
1 \text {; Diclazuril } 1 \text {; Avilamy } \\
5 \text { diets contained: } 12.97 \\
\text { Ileu } 8.4 \text {; His } 5.03 \text {; Arg }\end{array}$ & $\begin{array}{l}\text { nt } 1 ;{ }^{2} \text { diet } \\
\text { ac Dry, Ci } \\
\text { Citromix I } \\
\text { rovided pe } \\
\text { a protein is } \\
(98 \%) 0 . \\
\text { te } 17 ; \mathrm{Na} \\
\text { ng: vit. E } \\
75 ; \text { Ca pan } \\
\text { ycin } 10) \\
\text { MJ ME/k } \\
13.54 ; \mathrm{Le}\end{array}$ & $\begin{array}{l}\text { ts used in } \\
\text { itromlek P } \\
\text { Plus } \\
\text { er kg diet } \\
\text { isolate } 7 \text {; } \\
\text { 5; L-isole } \\
\text { Cl 3; vit } \\
\text { 40; vit. B } \\
\text { ntothenate } \\
\text {; } 210.4\end{array}$ & $\begin{array}{l}\text { Experime } \\
\text { Plus, Nord } \\
\text { (g): maize } \\
\text { rapeseed } \\
\text { eucine } 0.5 \\
\text { tamin-min } \\
3 \text {; vit. B } \\
\text { e } 15 \text {; choli } \\
\text { g CP } / \mathrm{kg} \mathrm{a}\end{array}$ & $\begin{array}{l}\text { ent } 2 \\
\text { locid Vect } \\
\text { e } 383.1 \text {; n } \\
\text { oil } 43.17 \\
5 \text {; Avizym } \\
\text { neral pren } \\
3_{2} 8 \text {; biotin } \\
\text { line } 500 \text {; } 1\end{array}$ & $\begin{array}{l}1, \text { Nordo } \\
\text { heat } 200 \\
\text { L-lysine } \\
1300 \\
\text { ix } 5 \text { (in } \\
0.1 \text {; vit } \\
\text { In } 80 \text {; } \mathrm{Zr}\end{array}$ & $\begin{array}{l}\text { id P2, } \\
\text { yellow } \\
(78 \%) \\
\text { innfee } \\
\text { : vit. } \\
\mathrm{B}_{6} 5 ; \mathrm{v}\end{array}$ & $\begin{array}{l}\text { romix or } \\
\text { upin var. } \\
5 \text {; DL-m } \\
\text { Int.) } 1 ; 1 \\
13500 \mathrm{IL} \\
\mathrm{B}_{120.03} \text {; } \\
2 ; \mathrm{Cu} 15\end{array}$ & $\begin{array}{l}\text { Citromix } \\
\text { olo 200; } \\
\text { ethionine } \\
\text { imestone } \\
\text { J; vit. D } \\
\text { vit. K 4; } \\
\text { Fe 70; J } \\
\text { Thr 7.35; }\end{array}$ \\
\hline
\end{tabular}

The diet was supplemented with minerals and vitamins, crystalline lysine, methionine, threonine and isoleucine to meet the requirement of broiler chickens (NRC, 1994). In Experiment 1 diet D was supplemented with $0.63 \mathrm{~g} \mathrm{TRP} / \mathrm{kg}$ (diet T3; Table 1) and prepared without or with $3 \mathrm{~g} / \mathrm{kg}$ of the following acidifiers: Acid Lac Dry (lactic, fumaric, citric, propionic and formic acids), Citromlek Plus (phosphoric, citric, fumaric and lactic acids), Nordocid Vectol (o-phosphoric, fumaric and sorbic acids and Ca-formate), Nordocid P2 (o-phosphoric, fumaric, citric and propionic acids, $\mathrm{Na}$ - and $\mathrm{Ca}$-propionate, $\mathrm{Ca}$-formate and K-sorbate), Citromix (phosphoric and citric acids) and Citromix Plus (phosphoric, citric and fumaric acids). In Experiment 2 diet D was supplemented with $0.21,0.42$ or $0.63 \mathrm{~g}$ crystalline L-TRP per $\mathrm{kg}$, each diet was prepared without or with $3 \mathrm{~g} / \mathrm{kg}$ of the Citromix Plus (Table 1). TRP and A substituted maize starch. Diets were cold pelleted.

\section{Animals and procedures}

Experiment 1 was carried out on 112 ten-day-old Cobb broiler females. Birds were randomly allocated into 7 groups, 16 birds in group and fed for 4 days ad libitum with the diet T3 (Table 1), without or with acidifiers. On the fifth day chickens were sacrificed, the abdominal cavity was opened and the digesta from crop, proventriculus/gizzard, jejunum, ileum and caeca was separately collected. The diges- 
ta from each part of the gastrointestinal tract was pooled within 4 chickens, weighed, mixed with deionised water (w/w), and their $\mathrm{pH}$ was immediately measured.

Experiment 2 was performed on 96 Cobb broiler females. During the first week of life chickens were fed a standard Starter diet. At 8th day of age birds were deprived of feed for $4 \mathrm{~h}$, weighed and randomly allocated into 8 groups, 12 birds in group, the average body weight (BW) in group was $183 \pm 2 \mathrm{~g}$. Birds were placed in individual cages and fed experimental diets (Table 1) ad libitum for 3 weeks. BW and feed intake was recorded weekly, body weight gain (BWG) and feed conversion ratio (FCR) were calculated.

From 29th day of life chickens were fed the same diets (Table 1) with $3 \mathrm{~g} / \mathrm{kg}$ of $\mathrm{Cr}_{2} \mathrm{O}_{3}$ added as a marker prior to pelleting, and balance experiment was performed according to Bourdillon et al. (1990). The meal was restricted to $90 \mathrm{~g}$ per bird per day offered in 3 portions. After 2 days, birds were deprived of feed for $12 \mathrm{~h}$, then fed with the same diets for the next 2 days and again deprived of feed for $12 \mathrm{~h}$. Droppings were collected quantitatively during two days of feeding and following $12 \mathrm{~h}$ starvation, and stored at $-18^{\circ} \mathrm{C}$. Birds were refed with the same diets ad libitum for two days and next they were sacrificed, the digesta from crop, stomach, jejunum, ileum and caeca were separately collected and their $\mathrm{pH}$ measured as in Experiment 1 . The digesta from the distal ileum (the last $15 \mathrm{~cm}$ from the ileo-caeco-rectal junction) were pooled within 3 chickens and stored at $-18^{\circ} \mathrm{C}$. In 6 birds from each group the skull was opened, the whole brain was immediately collected, frozen and kept at $-80^{\circ} \mathrm{C}$ for further analysis.

\section{Chemical analysis}

Diets, droppings and ileal digesta were analysed for moisture, nitrogen and crude ash according to AOAC (1990). Chromium oxide was determined spectrophotometrically following wet ashing according to Hinsberg et al. (1953). Faecal N in droppings was determined according to Ekman et al. (1949). The amino acid analyses were performed with Beckman 6300 High Pressure Amino Acid Analyser after digestion in $6 \mathrm{~N} \mathrm{HCl}$. Methionine and cystine content was determined in samples oxidized with performic acid prior to hydrolysis, tryptophan in samples digested with barium hydroxide according to Buraczewska and Buraczewski (1984).

\section{HPLC analysis}

Brains were thawed, homogenized at $0^{\circ} \mathrm{C}$ in $0.1 \mathrm{M} \mathrm{HClO}_{4}(1: 10$, w/v) with $200 \mathrm{ng}$ of 5-hydroxyindol (5-HI) added as an internal standard, and samples were centrifuged at $12000 \mathrm{~g}$ for $15 \mathrm{~min}$. The content of 5-HT and 5-HIAA was determined on HPLC apparatus (Waters 510) coupled with an electrochemical detector (Hewlett Packard 1049A) equipped with a glassy carbon working electrode and $\mathrm{Ag} / \mathrm{AgCl}$ reference electrode. The electrochemical detector was 
set at an oxidative potential of $0.650 \mathrm{~V}$. Ten $\mu \mathrm{l}$ of supernatant was injected on LC-18-DB $(15 \mathrm{~cm} \times 4.6 \mathrm{~mm}$ ID, $5 \mu \mathrm{m})$ Supelco column protected by a superguard LC-18-DB $5 \mu \mathrm{m}$ Supercosil, $2 \mathrm{~cm}$ precolumn and was eluted isocratically with a mobile phase consisting of $0.01 \mathrm{~mol} / \mathrm{L} \mathrm{NaCl}, 0.001 \mathrm{~mol} / \mathrm{L} \mathrm{EDTA}, 10 \% \mathrm{CH}_{3} \mathrm{OH}$, the $\mathrm{pH}$ of mobile phase was 3.6. The mobile phase was filtered through a $0.22 \mu \mathrm{m}$ GVWP membrane and degassed under vacuum with ultrasonic agitation. The flow rate was set at $0.8 \mathrm{ml} / \mathrm{min}$. The limit of detection was $10 \mathrm{pg} / 50 \mu \mathrm{l}$ for $5-\mathrm{HT}$ and $5 \mathrm{pg} / 50 \mu \mathrm{l}$ for 5-HIAA. Final concentrations of 5-HT and 5-HIAA in supernatants were calculated relative to internal standard recovery and expressed in $\mu \mathrm{g} / \mathrm{g}$ brain tissue.

\section{Calculations and statistical analysis}

The apparent faecal and ileal digestibility of protein and amino acids, faecal nitrogen and organic matter retention were calculated relative to the chromic oxide content. Data were analysed by one-way (Experiment 1) and two-way (Experiment 2) ANOVA (Statgraphic Plus ver. 5.1. 1994-2001).

\section{RESULTS}

Experiment 1. Neither of acidifiers investigated in Experiment 1 affected $\mathrm{pH}$ of digesta in crop and jejunum (Table 2). In the content of proventriculus/gizzard and ileum $\mathrm{pH}$ was lower, while in caecal contents higher in chickens fed diet supplemented with Cytromix Plus, than with other acidifiers, some of differences being significant $(\mathrm{P}<0.05)$, and this acidifier was used in Experiment 2.

TABLE 2

Effect of different acidifiers on $\mathrm{pH}$ of digesta in 14 day old broiler chickens (Experiment 1)

\begin{tabular}{lllllll}
\hline \multirow{2}{*}{ Group } & \multirow{2}{*}{ Acidifier } & crop & $\begin{array}{c}\text { proventriculus } \\
\text { and gizzard }\end{array}$ & jejunum & ileum & caeca \\
\cline { 3 - 7 } & Without acidifier & 4.71 & $2.50^{\mathrm{aA}}$ & 6.35 & $7.57^{\mathrm{b}}$ & $6.20^{\mathrm{abcA}}$ \\
\hline 1 & Acid Lac Dry & 4.56 & $3.15^{\mathrm{cB}}$ & 6.20 & $7.61^{\mathrm{b}}$ & $6.07^{\mathrm{aA}}$ \\
2 & Citromlek Plus & 4.63 & $3.12^{\mathrm{cB}}$ & 6.29 & $7.36^{\mathrm{ab}}$ & $6.39^{\mathrm{cdAB}}$ \\
3 & Nordocid Vectol & 4.62 & $2.97^{\mathrm{bcAB}}$ & 6.31 & $7.74^{\mathrm{b}}$ & $6.10^{\mathrm{abA}}$ \\
5 & Nordocid P2 & 4.75 & $2.80^{\mathrm{abcAB}}$ & 6.29 & $7.60^{\mathrm{b}}$ & $6.34^{\mathrm{bcAB}}$ \\
6 & Citromix & 4.71 & $2.73^{\mathrm{abcAB}}$ & 6.24 & $7.44^{\mathrm{ab}}$ & $6.08^{\mathrm{abA}}$ \\
7 & Citromix Plus & 4.72 & $2.59^{\mathrm{abAB}}$ & 6.24 & $7.14^{\mathrm{a}}$ & $6.62^{\mathrm{dB}}$ \\
\multicolumn{2}{l}{ Pooled SEM } & 0.12 & 0.16 & 0.07 & 0.16 & 0.09 \\
\hline ab,AB &
\end{tabular}

Experiment 2. Birds in groups fed diets most deficient in TRP ate less feed and had significantly $(\mathrm{P}<0.05)$ worse FCR and BWG than in other groups. Supplementation 
of the diet with graded levels of TRP caused insignificant increase of feed intake and significant $(\mathrm{P}<0.05)$ increase of BWG and improvement of FCR. Supplementation of diets with A had no significant effect on the performance of chickens (Table 3).

TABLE 3

Effect of tryptophan level and acidifier supplement on performance of broilers between 8 and 27 day of life (Experiment 2)

\begin{tabular}{lccc}
\hline $\begin{array}{l}\text { Dietary } \\
\text { treatment }\end{array}$ & $\begin{array}{c}\text { BWG } \\
\mathrm{g}\end{array}$ & $\begin{array}{c}\text { Feed intake } \\
\mathrm{g}\end{array}$ & $\begin{array}{c}\text { FCR } \\
\mathrm{g} / \mathrm{g}\end{array}$ \\
\hline $\begin{array}{l}\text { Tryptophan, g/kg diet } \\
1.57\end{array}$ & $1073^{\mathrm{a}}$ & 1620 & $1.51^{\mathrm{aA}}$ \\
1.78 & $1144^{\mathrm{b}}$ & 1687 & $1.48^{\mathrm{aAB}}$ \\
1.99 & $1172^{\mathrm{b}}$ & 1718 & $1.47^{\mathrm{abAB}}$ \\
2.20 & $1147^{\mathrm{b}}$ & 1678 & $1.46^{\mathrm{bB}}$ \\
Acidifier, g/kg diet & & \\
0 & 1121 & 1661 & 1.47 \\
3 & 1147 & 1691 & 1.48 \\
Pooled SEM & 27 & 43 & 0.02 \\
\hline ab, AB means in columns within the dietary treatment with no common superscripts were significantly diffe- \\
rent atP $<0.05$ and $\mathrm{P}<0.01$. Neither interactions between tryptophan level and acidifier were significant
\end{tabular}

In balance experiment it was found, that apparent protein digestibility, apparent nitrogen retention and organic matter retention was significantly higher $(\mathrm{P}<0.05$ or 0.01) in the group fed diet with lowest TRP level than in other groups. Organic matter retention was slightly but significantly $(\mathrm{P}<0.05)$ higher in groups fed diets with acidifier (Table 4). Apparent ileal digestibility of amino acids did not differ due to TRP level or acidifier presence in the diet (Table 5).

TABLE 4

Effect of tryptophan level and acidifier supplement on faecal apparent protein digestibility, nitrogen retention and organic matter retention, \% (Experiment 2)

\begin{tabular}{lccc}
\hline $\begin{array}{l}\text { Dietary } \\
\text { treatment }\end{array}$ & $\begin{array}{c}\text { Apparent protein } \\
\text { digestibility }\end{array}$ & $\begin{array}{c}\text { Nitrogen } \\
\text { retention }\end{array}$ & $\begin{array}{c}\text { Organic matter } \\
\text { retention }\end{array}$ \\
\hline $\begin{array}{l}\text { Tryptophan, g/kg diet } \\
1.57\end{array}$ & $90.7^{\mathrm{B}}$ & $58.4^{\mathrm{bB}}$ & $80.5^{\mathrm{B}}$ \\
1.78 & $90.3^{\mathrm{AB}}$ & $55.4^{\mathrm{aAB}}$ & $79.1^{\mathrm{A}}$ \\
1.99 & $89.9^{\mathrm{A}}$ & $54.5^{\mathrm{aA}}$ & $78.8^{\mathrm{A}}$ \\
2.20 & $89.8^{\mathrm{A}}$ & $55.1^{\mathrm{aAB}}$ & $79.2^{\mathrm{A}}$ \\
& & & \\
Acidifier, g/kg diet & 90.3 & 55.7 & $79.6^{\mathrm{b}}$ \\
0 & 90.0 & 56.0 & $79.2^{\mathrm{a}}$ \\
3 & 0.3 & 1.3 & 0.3 \\
Pooled SEM & & & \\
${ }_{\text {ab, AB }}$ means in columns within the dietary treatment with no common superscripts were significantly \\
different at ${ }^{\mathrm{ab}} \mathrm{P}<0.05$ and ${ }^{\mathrm{AB}} \mathrm{P}<0.01$. Neither interactions between tryptophan level and acidifier were \\
significant
\end{tabular}


TABLE 5

Apparent ileal digestibility of protein and amino acids in diets deficient (D) or supplemented with tryptophan (T3) without acidifier, or with acidifier (DA and TA3), \% (Experiment 2)

\begin{tabular}{lccccc}
\hline \multirow{2}{*}{ Amino acid } & \multicolumn{3}{c}{ Diet $^{1}$} & Pooled \\
\cline { 2 - 3 } & $\mathrm{D}$ & $\mathrm{T} 3$ & $\mathrm{DA}$ & $\mathrm{TA3}$ & SEM \\
\hline Protein & 87.1 & 87.1 & 86.6 & 86.8 & 0.99 \\
Asp & 82.4 & 81.1 & 81.0 & 82.5 & 1.65 \\
Thr & 82.5 & 82.0 & 81.8 & 82.7 & 1.71 \\
Ser & 86.0 & 85.6 & 85.4 & 86.2 & 1.32 \\
Glu & 91.4 & 91.3 & 91.1 & 91.5 & 0.92 \\
Pro & 89.5 & 89.7 & 89.4 & 89.8 & 1.07 \\
Gly & 82.2 & 81.2 & 81.5 & 81.8 & 1.68 \\
Ala & 87.5 & 87.6 & 87.6 & 87.5 & 1.44 \\
Val & 84.7 & 84.5 & 84.3 & 84.9 & 1.63 \\
Ile & 86.4 & 85.8 & 85.6 & 86.6 & 1.31 \\
Leu & 90.2 & 90.4 & 89.9 & 90.7 & 1.07 \\
Tyr & 86.2 & 86.7 & 85.4 & 87.5 & 1.53 \\
Phe & 89.9 & 89.7 & 89.2 & 90.4 & 1.17 \\
His & 87.1 & 86.3 & 86.7 & 86.7 & 1.26 \\
Lys & 89.0 & 88.3 & 88.2 & 89.1 & 1.19 \\
Arg & 92.1 & 91.6 & 91.9 & 91.9 & 0.77 \\
Cys & 82.9 & 81.9 & 82.1 & 82.7 & 1.41 \\
Met & 89.9 & 89.4 & 89.4 & 89.9 & 1.10 \\
Trp & 82.5 & 85.2 & 83.0 & 84.0 & 1.59 \\
\hline
\end{tabular}

${ }^{1}$ in the diets T1 and T2 only the ileal digestibility of protein and tryptophan was determined, it was, respectively, in T1 86.0 and 82.7 ; in T2 86.6 and 83.7

The tryptophan level and acidifier supplement had not affected significantly any ileal digestibility values

The $\mathrm{pH}$ of digesta in different parts of the gastrointestinal tract were of similar values as in Experiment 1 and were not affected by acidifier, while some differences were noted due to different TRP levels (Table 6).

TABLE 6

Effect of tryptophan level and acidifier supplement on $\mathrm{pH}$ of digesta (Experiment 2)

\begin{tabular}{|c|c|c|c|c|c|}
\hline \multirow{2}{*}{$\begin{array}{l}\text { Dietary } \\
\text { treatment }\end{array}$} & \multicolumn{5}{|c|}{$\mathrm{pH}$ of digesta in } \\
\hline & crop & stomach & jejunum & ileum & caeca \\
\hline Tryptophan, g/kg & & & & & \\
\hline 1.57 & 4.33 & 3.23 & $6.10^{\mathrm{bc}}$ & 7.22 & $6.22^{\mathrm{ab}}$ \\
\hline 1.78 & 4.31 & 3.31 & $6.05^{\mathrm{ab}}$ & 7.14 & $6.19^{\mathrm{ab}}$ \\
\hline 1.99 & 4.29 & 3.39 & $5.94^{\mathrm{a}}$ & 7.14 & $6.41^{\mathrm{b}}$ \\
\hline 2.20 & 4.39 & 3.30 & $6.23^{\mathrm{c}}$ & 7.28 & $6.10^{\mathrm{a}}$ \\
\hline Acidifier, g/kg & & & & & \\
\hline 0 & 4.35 & 3.36 & 6.09 & 7.18 & 6.30 \\
\hline 3 & 4.32 & 3.25 & 6.07 & 7.21 & 6.16 \\
\hline Pooled SEM & 0.07 & 0.10 & 0.07 & 0.12 & 0.13 \\
\hline Trp $\times$ acidifier & NS & NS & 0.05 & NS & NS \\
\hline
\end{tabular}


The concentration of 5-HT, 5-HIAA and 5-HT/5-HIAA ratio in brain tissue was lowest in DA group fed TRP deficient diet with acidifier, followed by group D group fed TRP deficient diet without acidifier. Both increased highly significantly $(\mathrm{P}<0.01)$ with the increase of TRP level to $1.78 \mathrm{~g} / \mathrm{kg}$ diet (Table 7), however relative increase

TABLE 7

Effect of tryptophan level and acidifier supplement on concentration of serotonin (5-HT) and 5-hydroxy-indole-3-acetic acid (5-HIAA) in brain tissue of broilers, $\mu \mathrm{g} / \mathrm{g}$ (Experiment 2)

\begin{tabular}{lccc}
\hline $\begin{array}{l}\text { Dietary } \\
\text { treatment }\end{array}$ & 5-HT & 5-HIAA & 5-HIAA/ 5-HT \\
\hline Tryptophan, g/kg diet & & & \\
1.57 & $2.20^{\mathrm{A}}$ & $0.48^{\mathrm{aA}}$ & $0.22^{\mathrm{aA}}$ \\
1.78 & $2.97^{\mathrm{B}}$ & $0.83^{\mathrm{BB}}$ & $0.28^{\mathrm{bB}}$ \\
1.99 & $3.22^{\mathrm{B}}$ & $0.94^{\mathrm{BB}}$ & $0.29^{\mathrm{bB}}$ \\
2.20 & $3.08^{\mathrm{B}}$ & $0.92^{\mathrm{cB}}$ & $0.31^{\mathrm{cB}}$ \\
& & & \\
Acidifier, g/kg diet & $2.98^{\mathrm{a}}$ & 0.78 & $0.25^{\mathrm{A}}$ \\
0 & $2.75^{\mathrm{b}}$ & 0.80 & $0.30^{\mathrm{B}}$ \\
3 & 0.15 & 0.04 & 0.01 \\
Pooled SEM & 0.001 & 0.001 & 0.001 \\
Trp $\times$ acidifier & &
\end{tabular}

in T1 group was greater than in TA1 group, what was reflected as highly significant interaction $\mathrm{TRP} \times \mathrm{A}(\mathrm{P}<0.001)$. Further supplementation of diets with TRP caused only numerical increase in 5 -HT and significant $(\mathrm{P}<0.05)$ increase in 5-HIAA concentration. On average in brain tissue of birds fed diets with acidifier the level of 5-HT was lower $(\mathrm{P}<0.05)$, while the ratio of 5-HIAA/5-HT higher $(\mathrm{P}<0.01)$ than in chickens fed diets without acidifier (Table 7).

\section{DISCUSSION}

Until 1984 the requirement of broilers at the age 0-3 weeks for TRP was estimated as $2.3 \mathrm{~g} / \mathrm{kg}$ diet, later it was reduced to $2.0 \mathrm{~g} / \mathrm{kg}$ diet (NRC, 1984, 1994), but the experimental evidence concerning TRP requirement in broilers at these age is contradictory. Woodham and Deans (1975) used diets containing 18\% crude protein (CP) from natural ingredients and estimated TRP requirement for $1.3-1.4 \mathrm{~g} / \mathrm{kg}$, Smith and Waldroup (1988) used diets containing 15.34\% CP, supplemented with protein equivalent in the form of amino acids to $20 \% \mathrm{CP}$ level and calculated that TRP requirement was $1.6 \mathrm{~g} / \mathrm{kg}$, while Steinhart and Kirchgessner (1984) and Han et al. (1991) calculated TRP requirement as $1.9-2.2 \mathrm{~g} / \mathrm{kg}$ using diets containing about 
$25 \%$ CP. Basal diet used in present study had 21\% CP from natural ingredients and covered the chickens requirement for all amino acids, except for TRP, which fulfilled $78.5 \%$ of NRC (1994) requirement. Supplementation with crystalline TRP to the level 1.78 and $1.99 \mathrm{~g} / \mathrm{kg}$ diet improved performance, while further supplementation of the diet to the level of $2.2 \mathrm{~g}$ TRP $/ \mathrm{kg}$ caused the decrease of performance, what may indicate that that level of TRP exceeded the requirement. It confirmed the lowered estimation of TRP requirement of broilers published by NRC (1994).

Partanen et al. (1998) found in pigs an improvement of apparent ileal CP and several amino acids digestibility in the presence of organic acids, they attributed it to the reduced endogenous nitrogen and amino acid losses. In our study the presence of acidifier in diets did not affect significantly either ileal digestibility of amino acids, or apparent nitrogen retention and performance of chickens in comparison with groups fed diets without acidifier. Apparent ileal protein digestibility was lower then that measured at faecal level. There were no distinct differences due to TRP supplementation in apparent ileal protein and amino acid digestibility, while apparent protein digestibility and nitrogen retention measured at faecal level was higher in TRP deficient group, than in TRP supplemented groups. It contradicts the results of growth experiment and may indicate rather on lower synthesis of bacterial protein in distal parts of gastrointestinal tract of birds fed TRP-deficient diet, in comparison with birds fed diets supplemented with tryptophan.

The presence of acidifier in diets did not affect significantly $\mathrm{pH}$ of digesta, the differences in $\mathrm{pH}$ of jejunal and caecal digesta due to TRP content in diet seem to be accidental. It confirms the conclusions of Roth and Kirchgessner (1989), that diets rich in protein and minerals can resist changes in $\mathrm{pH}$. Also Partanen and Mroz (1999) underlined, that it has been proven difficult to demonstrate in vivo that dietary organic acids reduce gastric $\mathrm{pH}$ in pigs. Different theories are proposed to explain the modes of antibacterial activity of organic acids in gastrointestinal tract of animals, they are expected to be most effective in acidic gastric contents. The main goal of organic acids added to chicken diets is to create an environment at once favourable to growth and activity of acid-producing organisms and unfavourable to most pathogenic species (Izat et al., 1990; Thompson and Hinton, 1997). Benefits of this approach appear in reduced incidence of disease and increased efficiency of production (Vogt et al., 1982). Birds in present study were kept in a very clean environment, diets were supplemented with antibiotic growth promoter, there was no mortality during experiment, it may explain the negligible effect of added acidifier on performance indices.

The lowest concentration of 5-HT and 5-HIAA in brain tissue in groups fed unsupplemented diets indicated, together with significantly lower BWG in this group, that the level of TRP in these diet was inadequate both to protein and neurotransmitters synthesis. The concentration of 5-HT and 5-HIAA in brain tissue increased significantly $(\mathrm{P}<0.01)$ with the increase of TRP level in diet, what was accompanied with 
the increase in feed intake. The present findings are partly contradictory to Denbow et al. (1993) who reported, that supplemental dietary TRP increased brain 5-HT and 5-HIAA concentration in turkeys, but it had no effect on either BWG or feed intake. The 5-HIAA is the major 5-HT metabolite in the brain and its relationship to 5-HT is indicative of serotonin turnover (Colmenares et al., 1975). Both, 5-HT and 5-HIAA concentrations in brain tissue of broiler chickens measured in the present study were 4 to 5-fold higher, than reported by Rosebrough (1996), although the TRP levels in all but one diets used in the last study were much higher than chickens requirement. The observation common in both studies is that at $21 \% \mathrm{CP}$ level in diet the level of serotonin in brain tissue decrease, while the ratio of 5-HIAA/5-HT increase in response to excess of TRP in diet. There is a shortage of information concerning the possible effect of acidifiers on the metabolism of brain biogenic amines. The apparent lack of effect of acidifier on the ileal digestibility of tryptophan as well as higher $(\mathrm{P}<0.01)$ ratio of 5-HIAA/5-HT in brain tissue of birds fed diets with the acidifier may indicate, that the decrease in concentration of 5-HT in brain in presence of acidifier in diets was rather due to higher turnover rate, not due to lower supply of tryptophan for serotonin synthesis. The interactive effects of amino acid and acidifier supplementation on serotonine level and metabolism, indicate for a need of taking into account possible dietary effects on regulatory mechanisms and imply a very careful formulation of diets, when more than one nutritional factor is modified. The consequences of impaired level of serotonin may be important in practical conditions since they involve well-being and behaviour of birds.

\section{CONCLUSIONS}

Deficiency of tryptophan negatively affects body weight gain and serotonin and its metabolite concentrations in brain tissue in chickens. Supplementation of diets containing crystalline tryptophan with acidifier has no influence on growth parameters, while it decreases the level of serotonin and its metabolite in brain, which may indicate for impaired utilization of tryptophan for synthesis or metabolism of neurotransmitter.

\section{REFERENCES}

AOAC, 1990. Official Methods of Analysis, Association of Official Analytical Chemists. 15th Edition. Washington, DC

Baker D.H., Allen N.K., Kleise A.J., 1973. Efficiency of tryptophan as a niacin precursor in the young chick. J. Anim. Sci. 36, 299-303

Bourdillon A., Carré B., Conan L., Francesch M., Fuentes M., Hughebaert G., Janssen W.M.M.A., Leclercq B., Lessire M., McNab J., Rigoni M., Wiseman J., 1990. European reference method of in vivo determination of metabolisable energy in poultry: reproducibility, effect of age, comparison with predicted values. Brit. Poultry Sci. 31, 567-576 
Buraczewska L., Buraczewski S., 1984. A note on determination of methionine and tryptophan. In: T. Żebrowska, L. Buraczewska, S. Buraczewski, J. Kowalczyk, B. Pastuszewska (Editors). Proceedings of VI International Symposium on Amino Acids, Serock (Poland). Polish Scientific Publishers, Warszawa, pp. 47-50

Colmenares J.L., Wurtman R.J., Fernstrom J.D., 1975. Effect of ingestion of carbohydrate-fat meal on the levels and synthesis of 5-hydroxyindoles in various regions of the rat central nervous system. J. Neurochem. 25, 825-829

Denbow D.M., Hobbs F.C., Hulet R.M., Graham P.P., Potter L.M., 1993. Supplemental dietary L-tryptophan effects on growth, meat quality, and brain catecholamine and indolamine concentrations in turkeys. Brit. Poultry Sci. 34, 715-724

Ekman P., Emanuelson H., Fransson A., 1949. The digestibility of protein in poultry. KGL. Lantbruks.-Hogskol. Ann. 16, 749

Falkowski J.F., Aherne F.X., 1984. Fumaric and citric acid as feed additives in starter pig nutrition. J. Anim. Sci. 58, 935-938

Han Y., Suzuki H., Baker D.H., 1991. Histidine and tryptophan requirement of growing chicks. Poultry Sci. 70, 2148-2153

Hinsberg K., Cremer H.D., Schmid G., 1953. In: Hoppe-Seyler/Thierfelder-Handbuch der Physiologisch-und Patologisch-Chemischen Analyse. Springer-Verlag, Berlin, pp. 402-403

Izat A.L., Tidwell N.M., Thomas R.A., Reiber M.A., Adams M.H., Colberg M., Waldroup P.W., 1990. Effects of a buffered propionic acid in diets on the performance of broiler chickens and on microflora of the intestine and carcass. Poultry Sci. 69, 818-826

Laycock S.R., Ball R.O., 1990. Alleviation of hysteria in laying hens with dietary tryptophan. Can. J. Vet. Res. 54, 291-295

National Research Council, 1984, 1994. Nutrient Requirement of Poultry. 8th and 9th Edition. National Academy Press, Washington, DC

Partanen K., Mroz Z., 1999. Organic acids for performance enhancement in pig diets. Nutr. Res. Rev. 12, 117-145

Partanen K., Valaja J., Siljander-Rasi H., Jalava T., Panula S., 1998. Effects of carbadox or formic acid and diet type on ileal digestion of amino acids by pigs. J. Anim. Feed Sci. 7, Suppl. 1, 199-203

Patten J.D., Waldroup P.W., 1988. Use of organic acids in broiler diets. Poultry Sci. 67, 1178-1182

Rosebrough R.W., 1996. Crude protein and supplemental dietary tryptophan effects on growth and tissue neurotransmitter levels in the broiler chicken. Brit. J. Nutr. 76, 87-96

Roth F.X., Kirchgessner M., 1998. Organic acids as feed additives for young pigs: Nutritional and gastrointestinal effects. J. Anim. Feed Sci. 7, Suppl. 1, 25-33

Roth F.X., Kirchgessner M., 1989. Significance of dietary $\mathrm{pH}$ and buffering capacity in piglet nutrition. 1.pH and buffering capacity of diets supplemented with organic acids. Landwirt. Forschung 42, 157-167

Sève B., 1999. Physiological roles of tryptophan in pig nutrition. In: G. Heuther, W. Kochen, T. J. Simat, H. Steinhart (Editors). Tryptophan, Serotonin and Melatonin: Basic Aspects and Applications. Adv. Exp. Med. Biol. 467, 729-741

Smith N.K. Jr., Waldroup P.W., 1988. Estimation of the tryptophan requirement of male broiler chickens. Poultry Sci. 67, 1174-1177

SAS, 1994-2001. Statgraphics ${ }^{\circledR}$ ver.5.1. Statistical Graphics System by Statistical Graphic Corporation, USA

Steinhart H., Kirchgessner M., 1984. Investigations on the requirement of tryptophan for broilers. Arch. Geflügelk. 48, 150-155

Thompson J.L., Hinton M., 1997. Antibacterial activity of formic and propionic acids in the diet of hens on salmonella in the crop. Brit. Poultry Sci. 38, 59-65

Vogt H., Matthes S., Harnisch S., 1982. The effect of organic acids on the performances of broilers - 2nd report. Arch. Geflügelk. 46, 223-227

Woodham A.A., Deans P.S., 1975. Amino acid requirements of growing chickens. Brit. Poultry Sci. $16,269-287$ 


\section{STRESZCZENIE}

Wpływ dodatku preparatu zakwaszającego do diet zawierających zróżnicowane poziomy krystalicznego tryptofanu na wzrost, strawność i odłożenie białka oraz koncentrację serotoniny w mózgu kurcząt brojlerów

Celem badań było stwierdzenie czy dodatek preparatu zakwaszającego (A) do diety zawierającej krystaliczny tryptofan (TRP) nie wpływa ujemnie na wykorzystanie tego aminokwasu na potrzeby związane ze wzrostem i syntezą serotoniny u kurcząt brojlerów.

Osiem grup, liczących po 12 8-dniowych kurek, utrzymywanych indywidualnie, żywiono: dietą niedoborową zawierająca $1,57 \mathrm{~g}$ TRP/ $\mathrm{kg}$ lub dietami uzupełnionymi TRP w ilości 0,$21 ; 0,42$ lub $0,63 \mathrm{~g} / \mathrm{kg}$. Diety podawano bez lub z dodatkiem $3 \mathrm{~g} / \mathrm{kg}$ preparatu zakwaszającego (A - mieszanina kwasów: fosforowego, cytrynowego i fumarowego). Przez 3 tygodnie rejestrowano spożycie paszy i masę ciała kurcząt, następnie przeprowadzono doświadczenie bilansowe, a na zakończenie ptaki ubito i pobrano próby treści jelita cienkiego i tkanki mózgowej.

Dodatek TRP zwiększył przyrost masy ciała i poprawił wykorzystanie paszy, nie miał natomiast wpływu na strawność jelitową białka, a jego strawność ogólną w niewielkim stopniu obniżył. Koncentracja serotoniny (5-HT) i jej metabolitu, kwasu 5-hydroksy-indolo-3-octowego (5-HIAA), oraz stosunek 5-HIAA/5-HT zwiększały się wraz ze zwiększeniem poziomu TRP w diecie. Dodatek A nie miał istotnego wpływu na wskaźniki odchowu oraz strawność jelitową i ogólną białka, natomiast istotnie obniżył koncentrację 5-HT (2,75 vs 2,98 $\mu \mathrm{g} / \mathrm{g}$; P<0,05) i zwiększył stosunek 5-HIAA/5-HT $(0,30$ vs 0,$25 ; \mathrm{P}<0,01)$ w tkance mózgowej. Ten negatywny wpływ był najsilniejszy przy skarmianiu diety niedoborowej w TRP $($ TRP $\times \mathrm{A} ; \mathrm{P}<0,001)$, co wskazuje na potrzebę starannego bilansowania zawartości TRP $\mathrm{w}$ dietach zawierających preparaty zakwaszające. 